\title{
Chapter 10: ePortfolios: Integrating learning, creating connections and authentic assessments
}

\begin{abstract}
Alison White ${ }^{1}$
Abstract Over the past decade in the tertiary education environment, there has been an increasing level of importance placed on the integration of digital technologies to support student learning and prepare students for transition into the world of work. ePortfolios have been recognised as a digital technology that has the capacity to support student growth and development. Through the use of an ePortfolio a student can create a well-organised visually appealing record of their academic and professional knowledge, skills and attributes as well as practical achievements. The journey of the creation of the ePortfolio has the potential to develop a student's professional identity, supporting students to make connections between their learning, the associated assessment tasks and to assist in the preparation required for transitioning into employment. The effectiveness of an ePortfolio as a tool for lifelong learning is underpinned by common challenges faced by educators regarding the development of any learning activity. This chapter describes a conceptual framework of how to design and integrate learning activities for ePortfolios, how to support learning activities with authentic assessment that then contribute as evidence for collection and inclusion in ePortfolios and also how to assess ePortfolios through the use of rubrics. The final section of the chapter provides a case study example of how an ePortfolio project has been scaffolded and integrated into a postgraduate coursework program at Griffith University, the Graduate Diploma in Clinical Physiology, using the whole-of-program or program-wide approach.
\end{abstract}

Keywords: ePortfolios, program-wide, employability, professional identity, reflective practice, work integrated learning

\footnotetext{
${ }^{1}$ Alison White, School of Environment and Science,

Griffith University, Brisbane QLD 4109 Australia

alison.white@griffith.edu.au
} 


\subsection{Introduction}

\subsubsection{Learning portfolios and reflective thinking}

Portfolios have been increasingly used in higher education to promote reflective thinking and reflective practice. As Bourner highlighted "over the last decade, reflective learning has made increasing inroads into the higher education curriculum. Recognition of the accelerating pace and impact of technological change, economic change and social change has created awareness of the need for graduates to be lifelong learners" (Bourner, 2003, p. 267). This style of reflective Portfolio has also been described as a learning Portfolio, integrative Portfolio or a Growth and development Portfolio (Oermann, 2002, cited in Green, Wyllie \& Jackson 2014). Reflective practice promotes a more in-depth style of learning in which students are encouraged to analyse their past experiences to make meaning and "judgements about what has happened" (Dunn \& Musolino, 2011, p. 128). This style of Portfolio is arguably the most robust and beneficial style of Portfolio for assisting students to transition from the educational institution into the world of work. The learning ePortfolio encourages students to create an individual learning space and "allows learners to move beyond what they have learned to consider how they have learned and to understand the connections inherent in the creative process of learning" (Hallam \& Creagh, 2010, p.181).

Reflective writing in learning Portfolios is utilised widely in university courses that include a Work Integrated Learning (WIL) component, particularly those courses which require competencies to be demonstrated during the WIL experience. A benefit of this style of Portfolio lies in its' ability to integrate and assess reflection as a means for students to connect experiences in the WIL environment to learning objectives for the chosen course of study (Tailor, Dubrey, Das, 2014; Curtis \& Wang, 2012). In the WIL environment, students participate in experiential learning opportunities where experiential is defined as students "learning by doing rather than learn(ing) through telling" (Buzzetto-More \& Alade, 2008). Experiential learning can take a variety of forms ranging from observational experiences to problem-based learning projects to authentic worksite placements incorporating an internship-style of professional placement. From the student perspective, the incorporation of WIL into an academic course provides an opportunity to integrate theoretical knowledge with practical application in real-world situations, thus providing authentic learning opportunities (McLachlan, Yeomans \& Lim, 2017). Students collect evidence of their WIL experiences for their portfolio and using reflective practice analyse their development in learning and change in knowledge that has occurred because of their WIL experience. This reflective process provides students a formal opportunity to consider their successes and explore areas for growth. In doing so, students are encouraged to identify their values and how these 
influence their professional behaviours as well as facilitate goal setting. Reflection aids to shift learning from teacher-directed to student self-directed learning "where students take responsibility for their own learning" (Buzzett-More \& Alade, 2008). As Curtis and Wang emphasised, "ePortfolios have been recognized for their ability to support the learner's self-reflection" (Curtis \& Wang, 2012, p.70). This style of Portfolio is referred to by some authors as an Integrative Portfolio (Fitch et al., 2008).

A strength of learning Portfolios is the incorporation of reflective thinking and critical analysis. Through the process of reflective thinking, students begin to create connections; linking past knowledge and experiences to current practice and examining areas for future development. By 'looking backward' reflecting on past experiences students create connections between their current knowledge and identify gaps and areas for future development, that is, 'looking forward.' In learning Portfolios, students are encouraged to create a narrative that describes the importance of the inclusion of each piece of evidence explaining its' significance and how it has contributed to their learning (Andre, 2010). By students considering the value of each artefact or piece of evidence that they choose to include in the ePortfolio, students undertake a form of self-assessment, reviewing and appraising each artefact which ultimately "empowers students to become the drivers of their own development" (Pelliccione \& Dixon, 2008, p. 759).

This process of considering each artefact supports critical thinking and reasoning, enabling students to project forward to future practice fostering the development of a professional identity (Andre, Heartfield \& Cusack, 2017). MatthewsDeNatale describes the purpose of the learning Portfolio as to "engage students in iterative cycles of creating work, reflecting upon work, revising work in response to metacognition, and integrating revised work within a larger context of professional and/or learning identity formation" (Matthew-DeNatale, 2013, p.2). The significant benefit and the underpinning concept of a learning Portfolio is this stepwise process of 'collect-select-reflect-connect' which supports learning first and assessment second (Hughes, 2008). Thus focusing assessment for learning rather than assessment on learning (Barrett, 2007).

\subsection{2 ePortfolios: Benefits, and challenges}

The capacity for students to utilize ePortfolios to assist their transition into the world of work, to develop their 'employability', is also increasing in recognition. ePortfolios are not only relevant to arts, education, and health professionals but are gaining importance for undergraduate Science, Technology, Engineering and Maths (STEM) STEM students with research in the US suggesting that ePortfolios will become a necessary tool for students to demonstrate to prospective employers their growth, development, and attainment of STEM skills (Brubaker, 2015).

The strengths of applying reflective practice in the learning ePortfolio are well recognized as the ePortfolio platform allows students to appraise the application and 
relevance of their selection of artefacts, provide links to external artefacts to further support relevance and to allow feedback via collaborative learning environments (Andre, 2010).

Through the use of an ePortfolio students can create a well-organised, visually appealing record of their academic and professional knowledge, skills and attributes, as well as practical achievements in WIL learning opportunities. The ePortfolio supports students to make connections between their learning objectives and learning goals, the associated assessment tasks, the skills developed through WIL projects and the preparation required for transitioning into employment. The concepts of both authentic learning, in which learning is connected to and supported by real-world examples as well as experiential learning. As stated by Matthews-DeNatale (2013), "ePortfolios are a key strategy for connecting workplace-based experiential learning and academic coursework" (p.4). ePortfolios are frequently used in teacher education and healthcare disciplines. With an increasing number of STEM university courses incorporating experiential learning activities as core components of the curriculum, the use of ePortfolios in the learning and teaching of STEM students is an area primed for exponential growth. The key benefits of an ePortfolio embedded within the curriculum in higher education are summarized in Table 1.

Table 10.1 The benefits that ePortfolios bring to learning and teaching

\begin{tabular}{|c|c|}
\hline Key Component & Description \\
\hline $\begin{array}{l}\text { Relevant and } \mathrm{Au}- \\
\text { thentic }\end{array}$ & $\begin{array}{l}\text { Students can create connections between learning objectives, assessment and } \\
\text { learning outcomes through the use of reflective practice. This develops self- } \\
\text { awareness, creates meaning in their learning (linking tacit with constructed } \\
\text { knowledge) and promotes a professional identity. Authentic learning is sup- } \\
\text { ported through experiential learning activities that are selected, collected and } \\
\text { reflected upon in the ePortfolio }\end{array}$ \\
\hline Accessible & $\begin{array}{l}\text { Students can quickly assemble and access evidence of learning offering a use- } \\
\text { ful tool to collect, select and reflect as well as efficiently draw on a broad } \\
\text { range of stored information via tagging of artefacts }\end{array}$ \\
\hline Sustainable & $\begin{array}{l}\text { Due to the transportable nature of ePortfolios, students are encouraged to en- } \\
\text { gage in lifelong learning utilising the ePortfolio beyond graduation }\end{array}$ \\
\hline Visible & $\begin{array}{l}\text { Allows different audiences to access evidence for specific needs; from 'inter- } \\
\text { nal' users (the student themselves for their learning journey and the academic } \\
\text { for assessment of student learning) to external users (employers, professional } \\
\text { associations, accrediting organisations) }\end{array}$ \\
\hline Scalable & $\begin{array}{l}\text { Allows integration across the curriculum from use in individual subjects to } \\
\text { across an entire course /program; a program-wide or whole-of-program ap- } \\
\text { proach }\end{array}$ \\
\hline
\end{tabular}




\subsubsection{Practical considerations and challenges to ePortfolio implementation}

As with any learning activity, particularly digital activities, there are challenges to the ePortfolio format.

ePortfolios can be time-consuming for the developer (student) if a lack of structure is provided on how to develop the ePortfolio. The student can lose sight of the purpose of an activity within the ePortfolio or lose sight of the meaning of the ePortfolio as a whole project. Clear instructions should be provided on the expectations regarding the minimum requirements of the evidence required to be demonstrated in the ePortfolio. The purpose of the ePortfolio needs to be clearly conveyed to the students so that they can create meaning and contextualise the ePortfolio process as an authentic component of both their learning and their assessment (Zaldivar, Summers \& Watson, 2011; Light, Chen \& Ittelson, 2011). As Reynolds and Patton (2014) state "If we don't make the goal explicit, our students don't have the opportunity to make this learning intentional" (p.43)

Students should also be provided with clear instructions on what not to include in their ePortfolio (Bacabac, 2013). If the purpose of the ePortfolio is to be an integrative or learning portfolio, it will be appropriate to show the development of learning over time. For example, the student may show a draft of an assessment item, reflect on that draft after receiving feedback from an instructor then display the final product, describing the development process (or action plan) thus evidencing their analysis skills and development of learning. However, if the ePortfolio is to be a professional portfolio for showcase purposes to external viewers, the process of including drafts, reflection on feedback and the final product would not be appropriate to add as the student should be including only the most relevant and best examples of work (Sutherland, Brotchie \& Chesney, 2011; Andre, Heartfield \& Cusack, 2017)

Students may struggle with the technical skills required to develop the ePortfolio; thus academics need to consider what IT support services will need to be provided and how students will access these. The opposite end of the scale is an IT savvy student who is comfortable with using new technologies. This type of student can become distracted by the technology of the ePortfolio itself and once again can lose sight of the purpose of the ePortfolio, creating a final product that may be aesthetically pleasing but lacks substantial or relevant content, i.e. 'all style, but no substance.'

Assessors of the ePortfolio (examiners) may require technical training and find the assessment process time consuming and open to subjective assessment, particularly if it is not supported by assessment rubrics (Andre, 2010; University of New South Wales [UNSW], 2018).

ePortfolios should be integrated across the degree program (a program-wide or whole-of-program approach) to ensure maximum learning opportunities. To have the ePortfolio as an assignment 'added' into one subject will diminish the value of the ePortfolio process for students, as students may view the ePortfolio task as a 
lesser priority and will tend to allocate less time to the project. By making the ePortfolio integrated within a course, it is made clear to students that there is an expectation that making connections is an integral part of their learning journey within the subject/course (Reynolds \& Patton, 2014). The integration of an ePortfolio across the life-cycle of a degree or program of study has the potential to increase student ownership of learning. Pelliccione and Dixon (2008) reflect that: "Instead of viewing their engagement with the program as working through discrete 'blocks' of learning that may or may not connect to each other, the students in the study described how they were able to 'see the whole picture' and therefore 'make sense' of their learning over the duration of the degree"(p.759). A program-wide or whole-of-program approach to ePortfolios is further supported by Housego and Parker (2009) who state that "whole-of-program ePortfolios could address a major issue in many existing programs - the lack of a coherent and effective approach to the learning and attainment of graduate attributes" (p. 418).

\subsection{Designing ePortfolio learning and assessment activities: Rethinking and redesigning curriculum}

\subsubsection{Considerations of curriculum and planning design}

The consideration of the implementation and integration of ePortfolios should not be taken lightly and needs to be supported by pedagogic evidence. The decision to incorporate ePortfolios must be preceded by a carefully considered approach in which the purpose of the ePortfolio and the context in which it will be used are identified and aligned (Watty \& McKay, 2015). Watty \& McKay (2015) argue that ePortfolio design must be "premised on thoughtful consideration of its pedagogical underpinnings explicitly aligned to student learning outcomes" (p.195). Scepticism may enter the decision process, and you may ask the question of 'Why ePortfolios?' As mentioned previously, the concept of a learning portfolio is not new to educational practice, however, momentum has gained on the whole-of-program implementation of ePortfolios due to the recognition of the strength and ability of ePortfolios to extend beyond the classroom and develop key aspects of student development, in particular, "skills and competencies; transformative potential; reflection; identity; active learning/student-centred engagement; employability; and assessment" (Watty \& McKay, 2015).

Several key steps should be considered in the process of implementing ePortfolios in the curriculum. These steps provide a practical approach to the planning and design of ePortfolios and are summarised in Figure 10.1 and are then further described in the text following. 

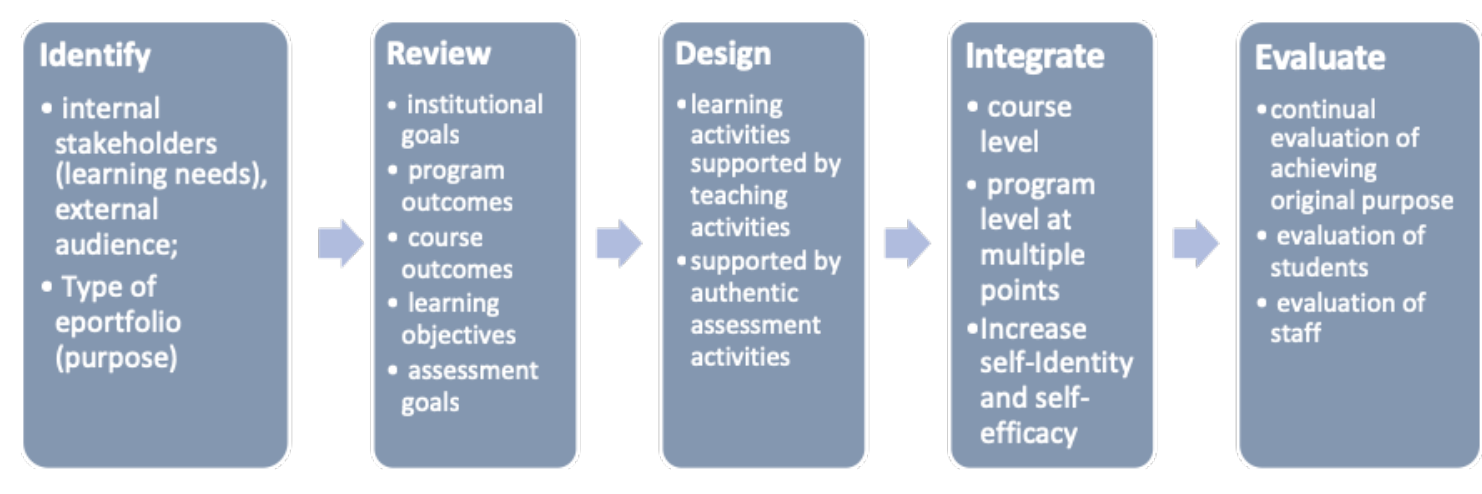

Fig. 10.1 Planning and Design Considerations for ePortfolios (Light, Chen \& Ittelson, 2011; Matthews-DeNatale, Blevins-Bohanan, Rothwell \& Wehlburg, 2017).

Identify: To understand the needs of the internal stakeholder (i.e. the student) start with revising the challenges that ePortfolios can present. For example, will the majority of your learners be technologically savvy, or will they struggle with the technical aspects of the ePortfolio? Are your students new to higher education (entering directly from secondary studies at the undergraduate level) or will they be postgraduate students? Knowing your students, their past experiences, their strengths and weaknesses assist in clarifying the learning needs of the students and thus define what the purpose of the ePortfolio will be for your students. There is equally a need to identify the requirements of the external audience or end-product users/viewers, which may be merely the student themselves or may include professional associations, regulatory bodies and potential employers.

Once you have reviewed the needs of both internal and external viewers it becomes simpler to define the purpose for the ePortfolio - is the ePorfolio to be a Showcase, Professional or Learning (Integrative) ePortfolio? What do you want your students to gain from the ePortfolio? What knowledge do you want them to seek and obtain? What concepts do you want the students to focus their learning on? Will you require students to demonstrate competency? How can students demonstrate their progression of learning?

Review: Each university has a version of graduate outcomes or attributes which are descriptions of the generic qualities and skills their graduates possess. Examples of graduate attributes include the possession of discipline-specific knowledge, communication skills, teamwork and collaboration skills, innovation and entrepreneurial skills. Many of the graduate attributes are generic or transferable skills. To support the program-wide integration of an ePortfolio the graduate attributes of the institution should be mapped across the program. ePortfolios can support the development of graduate attributes, as graduate attributes are developed over time across the life-cycle of the program and an ePortfolio if embedded across the program can serve as a repository to capture evidence of the development of graduate attributes (Housego \& Parker, 2009). Existing program level and course (subject) 
level learning outcomes should be reviewed to identify how an ePortfolio can meet and enhance these objectives. Drilling down to learning and assessment objectives in individual courses can then provide a 'best-fit' approach to the design phase of the ePorfolio which will ensure a 'fit-for-purpose' approach. Existing learning, teaching and assessment items within courses can be evaluated for their usefulness and appropriateness for inclusion in the ePortfolio, as several existing items may be able to be adapted or reframed to support the purpose of the ePortfolio (Housego \& Parker, 2009).

Design: Learning objectives or outcomes are the starting point for designing ePortfolio learning activities. Learning outcomes are measurable results that the student will have the opportunity to develop and demonstrate during a course. For learning outcomes to be a useful and robust tool to direct student learning, the learning outcome must be detailed and measurable (Reynolds \& Patton, 2014). The language of learning outcomes should be clear and explicit. Bloom's Revised Taxonomy of Educational Objectives (Anderson, Krathwohl \& Bloom, 2001) recognises increasing levels of cognition. The learning outcome verbs in the taxonomy can assist you to communicate to students what they are required to achieve. For example, the levels in the taxonomy (increasing from lowest to highest) are:

1. Remember (Knowledge): define, list, recognize, relate, acquire

\section{Comprehend (Understand): describe, explain, identify, discuss}

3. Apply (Application): demonstrate, implement, organize, relate, show

4. Analyse (Analysing): examine, differentiate, investigate

5. Synthesis (Creating): construct, design, organise

6. Evaluation (Evaluating): judge, critique, appraise

Fig. 10.2 Bloom's taxonomy adapted from Anderson, Krathwohl and Bloom (2001)

ePortfolios need to balance the priorities of learning and assessment as well as the needs of the students with the needs of the teaching staff. An important factor to consider when incorporating the use of ePortfolios in a program is to consider the principles and process of learning design. There are many different models of learning which can be utilised to design learning activities including Fink's Taxonomy of significant learning and Kolb's spiral of experiential learning. Kolb's theory of experiential learning is particularly applicable to the development of ePortfolio activities beginning with concrete experience, followed by reflective observation, abstract conceptualisation and active experimentation (Kolb, 1984). ePortfolios 
champion experiential learning when students are supported to carefully choose experiences that are supported by reflection, critical analysis and synthesis. Thus learning activities in ePortfolios must be student-centric, focused on learner control, permitting students to customise their learning environment to maximise the creation of connections (Tosh, Werdmuller, Chen, Light \& Haywood 2006). Learning and teaching activities need to be aligned with both learning outcomes and assessment methods to facilitate students to create meaning and augment student engagement (Light et al., 2011).

Integrate: As stated previously, when learning activities are integrated across a program of study where students are required to add evidence to their ePortfolio at several points throughout their program, students can make connections to their learning and are more able to self-assess and measure the extent of their learning. This, in turn, leads to an increase in students' perception of their level of engagement with their learning, their self-confidence, self-management and self-efficacy (Reynolds, 2014; Matthews-DeNatale, 2017; Bryant \& Chittum, 2013).

Evaluate: As with the introduction of any substantial change to the structure of learning, teaching or assessment, the process of embedding of an ePortfolio across a course or program should be evaluated for the level of achievement of the purpose and the desired outcomes of the change (Buzzetto-More \& Alade, 2008). The evaluation process should involve an appraisal of students regarding their interactions with the ePortfolio; did students perceive an increase in self-confidence? More indepth and broader connections with their learning? What additional skills did they develop through the use of the ePortfolio? Benefits and challenges for the academic in the embedding process should be equally evaluated to identify gaps for further training to in turn provide opportunities for continual beneficial progress to occur. Through this review process, the value of the ePortfolio can be measured and provide a means to "ensure purposeful longitudinal growth and continuous improvement within an academic culture committed to assurance of learning and student learning outcomes assessment" (Buzzetto-More \& Alade, 2008, p. 68).

\subsubsection{Considerations of the use of assessment in ePortfolios}

Assessment in ePortfolios can be used in the higher education field to "direct learning and to provide recognition of achievement" (Andre, 2017, p. 88). A key rationale for the use of assessment in ePortfolios is to provide the opportunity for both formative and summative assessment. The use of formative assessment in the early stages of the creation of an ePortfolio provides students with the opportunity to receive constructive feedback that can stimulate and support deeper learning. The use of summative feedback in the later stages of the ePortfolio allows students to select the most relevant and highest quality examples of their work. Scaffolding both summative and formative assessment in an ePortfolio supports the concept of an ePortfolio as a 'continuum' across the curriculum and the idea that ePortfolios are 
collections of work curated by the learner (Clarke \& Boud, 2016). The flexibility and adaptability of ePortfolios as an assessment tool "provides the student with authentic, reflective, interactive and individual features ... mak(ing) this a truly learner centered activity" (Mason, Pegler \& Weller, 2004, p. 719).

As part of the design of the assessment activities associated with the ePortfolio, a decision should be made regarding how the assessment will be graded. Will the assessment be graded throughout the degree program, thus providing a learning portfolio style in which regular feedback is given to students?; or will the ePortfolio be assessed as a stand-alone piece of work at the end of the program as a showcase ePortfolio? Obviously, there are disadvantages for both the student and the academic of grading at the end of the program. By grading only at the end of the program, progressive formative assessment is excluded, self-directed learning for the student is not facilitated, and the task of grading for staff can prove to be a potentially arduous undertaking to grade all the work at the end of the program (Reynolds, Candyce and Patton, 2014).

Assessing ePortfolios is not without its' challenge. A salient point to consider is the source of potential bias in the grading of ePortfolios, as examiners may be subjective in their assessment and may be "tempted to let irrelevant qualities, such as the quality of the writing, the structure and the lay-out of the portfolio sway their judgement" (Driessen, Overeem, Tartwiijk, Van Der Vleuten and Mujitjens, 2006, p. 863).

The use of grading rubrics can alleviate concerns regarding the subjectivity of the assessment process involved in ePortfolios. ePortfolio grading rubrics can provide validity and reliability to the assessment process (Andre, Heartfield \& Cusack, 2017; Light et al., 2011). This is particularly important given the number of reflective writing tasks included in the ePortfolio as well as the creative and technical components of the digital presentation of the ePortfolio. Referring back to the challenges of ePortfolios, assessors can find grading of ePortfolios arduous and timeconsuming in the absence of a clearly constructed rubric and hence rubrics that are student-focused and provide clear guidance in the levels of learning achievement have benefits for both the assessor and the student.

In summary, frequent opportunities for students to integrate reflections throughout the ePortfolio assessment on which assessors can provide regular formative feedback before the final summative assessment enhances the visibility of learning to both the student and external viewers (Light et al., 2011).

\subsection{A case example}

The Graduate Diploma of Clinical Physiology is a one-year professional program which integrates the development of clinical knowledge (the theory) with the practical application in a work integrated learning (WIL) context. The program consists of six courses in a two trimester model. In the first trimester (13 weeks of teaching) 
students complete four courses covering healthcare law and ethics, research methodology, communication skills, reflective practice, pathophysiology, analysis and interpretation of diagnostic test results and bioinstrumentation. These courses are delivered in a combination of face-to-face lectures, workshops, onsite workplace visits in the hospital environment and online learning. In the second trimester students complete 12 weeks of professional placement in a clinical WIL mode that encompasses two different areas of clinical physiology as well as attend face-toface workshops.

Graduates of the program seek employment as clinical measurement scientists in hospitals, and their role is centred around performing and interpreting diagnostic tests on patients. The profession into which these graduates are entering is a highly competitive market and one which requires students to possess more than discipline-specific knowledge. Graduates must equally possess a keen sense of awareness of their transferable skills.

The purpose of embedding an ePortfolio using a whole-of-program approach in the Graduate Diploma was to provide students with a tool through which they could collect, curate and communicate their academic and professional knowledge, skills and attributes as well as their practical achievements in the WIL environment. On face value this could be categorised as a Showcase portfolio; however, the overall aim of embedding the ePortfolio throughout the program was to support students to establish connections linking theory and practice across the student life-cycle: to transition in, transition through and transition out. This approach recognises that students' needs, identity and goals change across the journey through their program (Lizzio, 2011). By utilising an ePortfolio to support the student lifecycle, learning, teaching and assessment activities with a strong focus on engagement with reflective writing, an ePortfolio can be fully integrated to provide a learning ePortfolio rather than just a Showcase ePortfolio.

The starting point for the ePortfolio project in the Graduate Diploma was to review the program level outcomes and the institutional graduate outcomes, then amalgamate these in context with knowledge, skills and attributes required by employers (professional outcomes). The professional outcomes were identified by reviewing professional association mission statements, standards and guidelines as well as surveying peak industry representatives. An example of this process can be seen in Figure 10.3. 


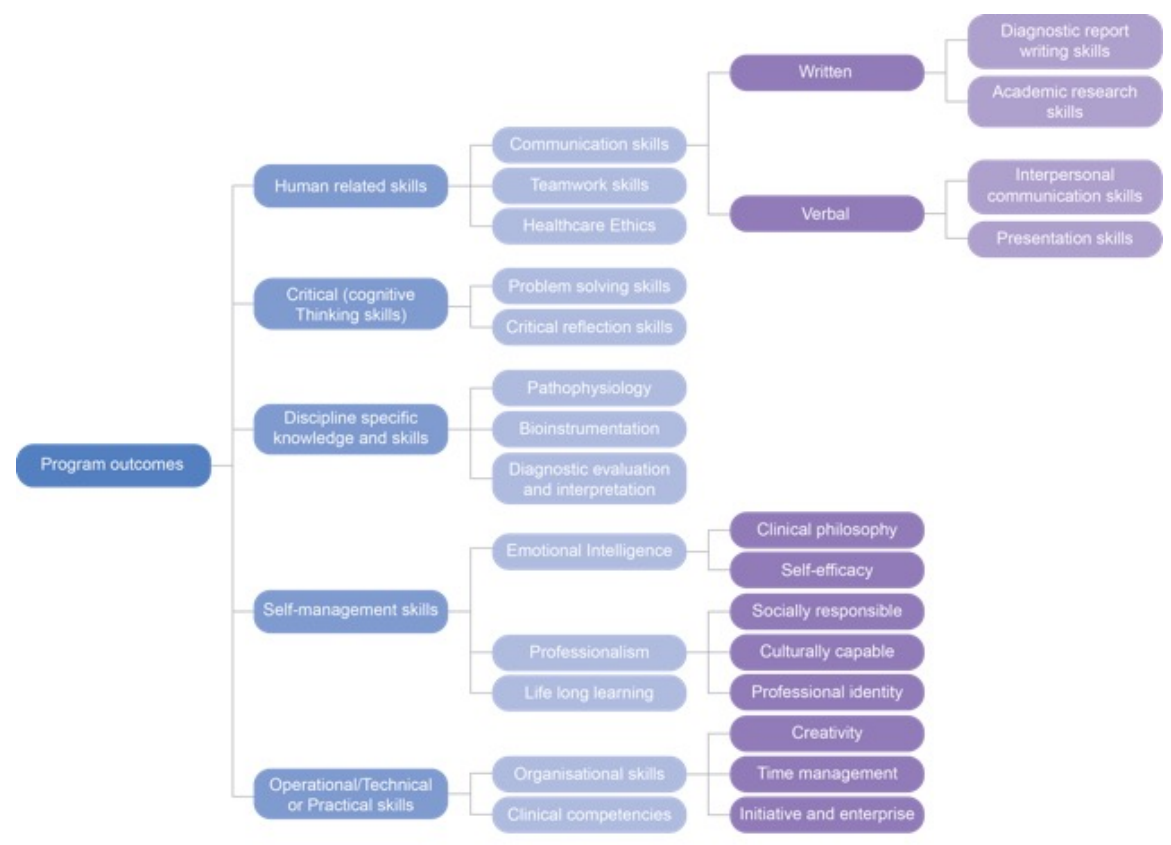

Fig. 10.3 Planning and Design Considerations for ePortfolios in the Graduate Diploma of Clinical Physiology

The next step was to identify the learning, teaching and assessment activities that currently existed in the program that supported the development of the desired outcomes and how these existing activities could be adapted or reframed and then integrated into the ePortfolio as evidence of the development of program level outcomes throughout the lifecycle of the program. This, in turn, enabled recognition of gaps in content delivery and learning support and identification of new ways to integrate additional learning opportunities into the ePortfolio.

Table 10.2 demonstrates how one of the program level outcomes, Human Related Skills, was mapped. The mapping process involved:

1. Assessing the program for existing learning and teaching activities that developed Human Related skills; this helped to identify any gaps in delivery and subsequently, further learning and teaching activities were then incorporated to further support this content.

2. Assessing the program for existing assessment activities that related to and developed Human Related skills and how these assessment items supported existing learning and teaching activities.

3. Identification of gaps in assessment activities and how assessment could be scaffolded throughout the program to support the learning and teaching activities over the life-cycle of the program. 
4. Identification of how students could produce and collect artefacts to be integrated into an ePortfolio to evidence their personal learning journey and thus the development of their Human Related Skills across the life-span of the program.

Of particular note when reading through Table 10.2, in the "Assessment Activity" column, existing assessment items were examined for their suitability for incorporation into an ePortfolio. What was identified was how these assessments could be adapted and included in the final ePortfolio project, which is shown in the "Artefacts to be integrated as ePortfolio evidence" column. This process involved students submitting the various pieces of assessment listed in the "Assessment Activity" column at various times during their program for both formative and summative assessment, receiving feedback on the assessments and then incorporating these assessment items as artefacts in their final ePortfolio submission. The students are encouraged to review the feedback and make appropriate alterations to their assessment before the final submission of the ePortfolio. By using this process students have the opportunity to take greater ownership of their learning and can further demonstrate the progression and development of their learning over time throughout the program.

Table 10.2 Program level mapping of ePortfolio activities for Human Related Skill

\begin{tabular}{|c|c|c|c|c|}
\hline $\begin{array}{l}\text { Human related } \\
\text { skills }\end{array}$ & Time in program & $\begin{array}{l}\text { Learning and } \\
\text { Teaching Ac- } \\
\text { tivity }\end{array}$ & Assessment Activity & $\begin{array}{l}\text { Artefacts to be inte- } \\
\text { grated as ePortfolio } \\
\text { evidence }\end{array}$ \\
\hline \multicolumn{5}{|l|}{$\begin{array}{l}\text { Communication } \\
\text { skills }\end{array}$} \\
\hline \multirow[t]{3}{*}{ written } & Trimester 1 & $\begin{array}{l}\text { Library re- } \\
\text { search skills, } \\
\text { academic writ- } \\
\text { ing skills and } \\
\text { academic integ- } \\
\text { rity workshop }\end{array}$ & $\begin{array}{l}\text { Pathophysiology re- } \\
\text { search assignment; Bio- } \\
\text { instrumentation equip- } \\
\text { ment comparison } \\
\text {-assignment }\end{array}$ & $\begin{array}{l}\text { Assignment excerpts } \\
\text { with links to full as- } \\
\text { signment with a sup- } \\
\text { portive statement }\end{array}$ \\
\hline & Trimester 2 & $\begin{array}{l}\text { Career planning } \\
\text { and placement } \\
\text { preparation } \\
\text { workshops }\end{array}$ & $\begin{array}{l}\text { Professional CV } \\
\text { Professional statement } \\
\text { Clinical case studies } \\
\text { (WIL) }\end{array}$ & $\begin{array}{l}\text { 'About Me' home } \\
\text { page written state- } \\
\text { ment }+/- \text { video vi- } \\
\text { gnette }\end{array}$ \\
\hline & & $\begin{array}{l}\text { Case studies } \\
\text { workshop }\end{array}$ & & \\
\hline
\end{tabular}




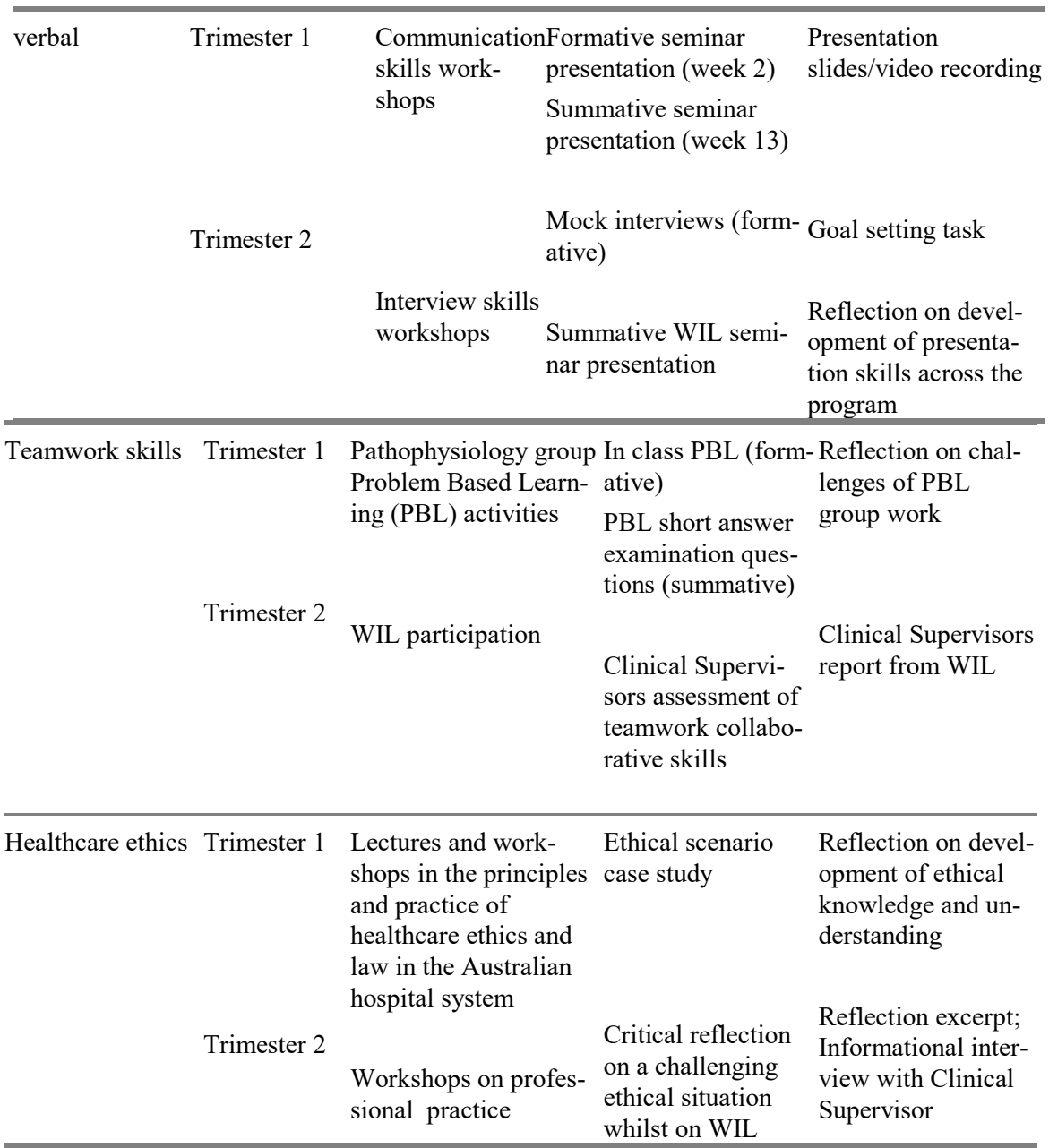

A key component acknowledged in the mapping process was identification of the lack of support for reflective writing in the program and the need to incorporate reflective practice and reflective writing into the ePortfolio project to allow the Portfolio to be process driven instead of product driven. As emphasised earlier in the chapter, reflection can be referred to as the "central pillar of ePortfolios" (Watty \& McKay, 2016, p. 199), promotes metacognitive skills and guides students to analyse rather than merely assimilate facts. This is underpinned by concepts regarding affective learning by Krathwhol, Bloom and Masia (1964) and follows Schon's (1983) theory of reflective practice.

In order to support reflective writing with a whole-of-program approach, it was identified through the mapping process that students needed to be presented with 
multiple opportunities to reflect from the beginning, through the middle and to the end of the program. The aim of utilising reflective writing through the program was to empower students to discriminate how their learning and skills had developed over the whole program; i.e. the power of 'making connections' and thus facilitate more-in-depth learning. Rowley et al. (2014) emphasises this point in which they state "The creation of the ePortfolio involves reflection, organisation and critical thinking by the student in how to develop a portfolio that accurately represents their skills learnt and competencies developed during their program of study". The most successful reflection occurs when reflection is scaffolded and supported by the educator.

As mentioned previously in the chapter, it is important to convey to the student the need to not just collect artefacts but to assimilate and evaluate the significance of the artefact that they have selected to include in the ePortfolio. This enhances the quality of the artefact and Andre (2017) draws attention to the point that an artefact in an ePortfolio is only truly converted to real evidence once the artefact has been reflected upon and validated in the context of the purpose of the ePortfolio. If an artefact is included merely for the sake of inclusion without the accompanying evaluation, then it is merely an object and does not meet the purpose or intended learning outcome (Andre, 2010). In the ePortfolio project in the Graduate Diploma, the decision was made that most artefacts would be accompanied by a brief supportive argument rationalising how the artefact enhanced learning and related to the purpose of the assessment activity and learning outcomes. By the student providing an explanation of why the artefact was included, context is provided for the inclusion of the artefact, which is an example of authentic learning. It was identified that some artefacts (e.g. certifications, log tally) that were collected from the students' WIL experience and that were required to be included in the ePortfolio did not warrant a supporting statement.

Central to the concept of the development of reflective writing in the ePortfolio project, it was important to make clear to students in assignment guideline statements, the requirement of the inclusion of supporting statements for the assignments. These assignments then formed compulsory elements in the ePortfolio. For example, in the assignment guidelines for the clinical case studies, students are instructed that when they include a case study in their ePortfolio, the case study must be accompanied by a supporting reflective statement. Prompts in the assignment guidelines to assist students to write their supporting statement include: "Explain what the major focus of each case study was, highlight the skills you developed in researching and writing each case study and how the case study contributed to your professional learning in the WIL environment on clinical placement. Your statement may be structured as a reflection on your previous knowledge in the content area and how this was expanded and developed through the research of the literature regarding the case study and informed your future professional practice". The learning objective for this task was for students to "examine changes and growth in personal learning in pathophysiological processes associated with your WIL experience and analyse how these changes integrated into the overall WIL experience.' 
This is a clear example of how the learning objective was linked with the assessment design and supported by reflective writing in the ePortfolio.

The process of reflection requires deliberate thought and awareness. Learning 'how to reflect' in a purposefully and meaningful manner can be an intellectually demanding task to which some students can be resistant to (Sutherland, Brotchie \& Chesney, 2011). Our initial experience with requiring students to produce reflective writing tasks was that many students struggled with reflective writing and felt that reflection was almost an alien experience to them. This experience reported by the students may have in part been due to the postgraduate students coming from an undergraduate scientific background, and as such, they felt more familiar with effective (cognitive) domains of reflection, rather than affective (metacognitive) domains of reflection. This experience is common amongst students who have not undertaken reflective writing before and as Dun-Pitt (2006) commented that "Reflection does not come naturally to all learners and the quality of reflection is variable" (Duncan-Pitt \& Sutherland, 2006, p. 73). Often students are reluctant to create honest and open reflections based on: fears of failure to meet assessment guidelines; a lack of trust or rapport with the assessing academic; wanting to complete the task merely to 'tick the box' rather than engage with the task or a desire to jump to a conclusion and not undertake an evaluative process (Andre, Heartfield \& Cusack, 2017; Duncan-Pitt \& Sutherland, 2006; Green et al., 2014). Reluctance by students to embrace reflective writing can diminish the educational benefit of reflection and can tip the balance of the reflective task to be product driven rather than the intended process driven (Barret, 2007). The initial experience of the lack of engagement with reflective writing in the postgraduate students in the program highlighted a gap in the support that was provided to students in the learning activities. Following on from this, for further iterations of the program, additional reflective practice and reflective writing workshops were then embedded in the curriculum in trimester 1 to create a safe and inclusive environment to stimulate in-class writing activities and the sharing of narrative in class, and to build trust in the leaner-teacher relationship (Green et al., 2014). The outcome of which, was that students began to focus more on creating connections and making sense of their learning rather than focusing on just 'getting through the task' and concentrating only on the writing prompts to frame their writing.

The ePortfolio as an assessment task in the Graduate Diploma consists of individual pieces of assessment (either formative or summative) across several courses embedded throughout the program. The ePortfolio itself is then assessed holistically as an entire entity at the end of the program when students submit the ePortfolio as their final piece of assessment with the requirement that the ePortfolio must be completed to complete the program.

There were four components of assessment that were identified as applying to the assessment of the final ePortfolio in the Graduate Diploma of Clinical Physiology:

- Technical construction and organisation

- Creativity/Visual design 
- Selection and communication of content

- Reflective ability

These four components of assessment were then linked back to the learning objectives of the program, and the overall purpose and aim of the ePortfolio and elements were determined for each of the areas of assessment. The expanded criteria for each of the areas of assessment are shown in Table 10.3.

Table 10.3 Components of assessment for ePortfolio grading in the Graduate Diploma of Clinical Physiology

\begin{tabular}{|c|c|c|}
\hline $\begin{array}{l}\text { Technical } \\
\text { Consideration and or- } \\
\text { ganisation }\end{array}$ & $\begin{array}{l}\text { Creativity/ } \\
\text { Visual Design }\end{array}$ & $\begin{array}{l}\text { Selection and communi- Reflective ability } \\
\text { cation of content }\end{array}$ \\
\hline $\begin{array}{l}\text { Clear and logical se- } \\
\text { quence and evident struc- } \\
\text { ture of the organisation o } \\
\text { the content } \\
\text { Degree of accessibility of } \\
\text { the content - the ease of } \\
\text { navigation } \\
\text { Quality of the construc- } \\
\text { tion of the index/contents } \\
\text { home page } \\
\text { Quality and construction } \\
\text { of each of the tabs (con- } \\
\text { tent areas) in the portfolic }\end{array}$ & $\begin{array}{l}\text { Degree of personalisation } \\
\text { - and engagement with the } \\
\text { fePortfolio } \\
\text { Degree of understanding of } \\
\text { f how the visual appearance } \\
\text { of the ePortfolio contributes } \\
\text { to professional identity } \\
\text { Demonstrated appropriate } \\
\text { use of multimedia } \\
\text { The quality of the design } \\
\text { and appearance of the } \\
\text { ePortfolio - the degree of } \\
\text { oappeal of the layout and de- } \\
\text { sign of the ePortfolio (this } \\
\text { includes the choice of back- } \\
\text { ground colour, readability } \\
\text { of the text, alignment and } \\
\text { positioning of content, the } \\
\text { use of the white space to } \\
\text { organise content) } \\
\text { Utilisation of formatting } \\
\text { tools }\end{array}$ & 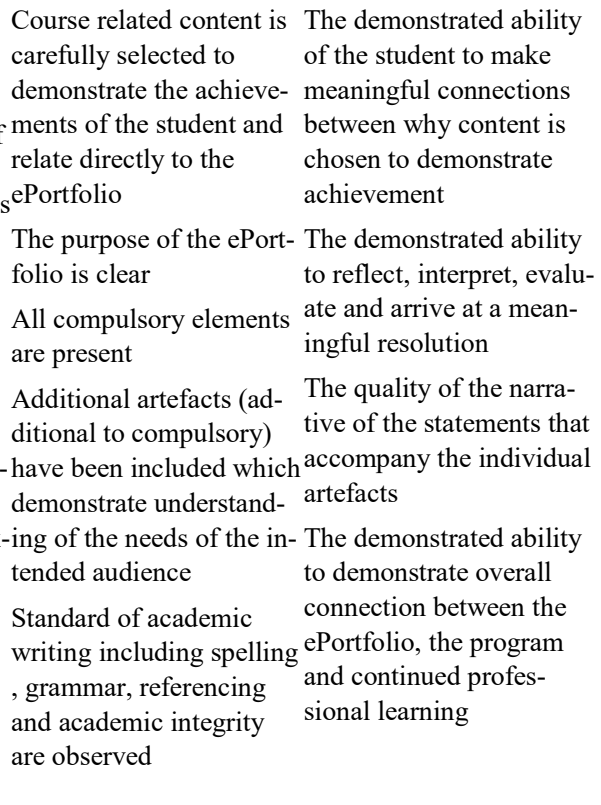 \\
\hline
\end{tabular}

In order to facilitate feedback and provide criteria for final grading of the ePortfolio, the assessment criteria shown in Table 10.3 were then used to develop a grading rubric. The experience with the grading rubric was initially mixed. The students found the rubric a positive and supportive experience and reported the benefits of having clear guidelines on how the assessment would be graded. The academic grading the assessment found that in the first iteration of grading the ePortfolios, the rubric was too heavily weighted on the technical and creativity aspects of the overall ePortfolio project. Based on this observation the grading rubric was altered to place a greater emphasis on the quality of the selection of content and the quantity and quality of the reflective writing in the ePortfolio. The reflective writing was assessed for the ability to support the inclusion of the artefact and to demonstrate progression of learning. The outcome of the alteration of the grading rubric to have 
a greater focus on the reflective component provided a closer alignment with the purpose of the ePortfolio as a learning or integrative ePortfolio. An extract from the grading rubric showing the standards for reflection is provided in Table 10.4.

Table 10.4 Extract showing reflective component of ePortfolio grading rubric Graduate Diploma of Clinical Physiology

\begin{tabular}{|c|c|c|c|c|c|}
\hline Description & Exemplary & Proficient & Developing & Novice & Unsatisfactory \\
\hline $\begin{array}{l}\text { Reflective abil- } \\
\text { ity (weighting } \\
30 \% \text { ) assign a } \\
\text { mark out of } 30 \\
\text { The demon- } \\
\text { strated ability of } \\
\text { the student to } \\
\text { make meaning- } \\
\text { ful connections } \\
\text { between why } \\
\text { content is cho- } \\
\text { sen to demon- } \\
\text { strate achieve- } \\
\text { ment } \\
\text { The demon- } \\
\text { strated ability to } \\
\text { reflect, inter- } \\
\text { pret, evaluate } \\
\text { and arrive at a } \\
\text { meaningful res- } \\
\text { olution } \\
\text { The quality of } \\
\text { the narrative of } \\
\text { the statements } \\
\text { that accompany } \\
\text { the individual } \\
\text { artefacts } \\
\text { The demon- } \\
\text { strated ability to } \\
\text { demonstrate } \\
\text { overall connec- } \\
\text { tion between the } \\
\text { ePortfolio, the } \\
\text { program and } \\
\text { continued pro- } \\
\text { fessional learn- } \\
\text { ing } \\
\end{array}$ & $\begin{array}{l}\text { Clear, compre- } \\
\text { hensive and in } \\
\text { depth disclosure } \\
\text { of events } \\
\text { Demonstrates a } \\
\text { highly sensitive } \\
\text { and insightful } \\
\text { willingness to } \\
\text { disclose per- } \\
\text { sonal thoughts } \\
\text { and share these } \\
\text { e with the reader. } \\
\text { All reflective } \\
\text { writing pieces } \\
\text { demonstrate the } \\
\text { ability to self- } \\
\text { critique in an } \\
\text { effective man- } \\
\text { ner and provide }\end{array}$ & $\begin{array}{l}\text { Clear and in } \\
\text { depth disclo- } \\
\text { sure of events } \\
\text { High level of } \\
\text { willingness to } \\
\text { disclose per- } \\
\text { sonal thoughts } \\
\text { and share these } \\
\text { with the } \\
\text { reader, } \\
\text { Demonstrates } \\
\text { a well-devel- } \\
\text { oped ability to } \\
\text { express their } \\
\text { feelings at a } \\
\text { significant } \\
\text { level of under- } \\
\text { standing } \\
\text { Most reflective } \\
\text { writing pieces } \\
\text { demonstrate }\end{array}$ & $\begin{array}{l}\text { Most content is } \\
\text { accompanied by } \\
\text { - a caption or ex- } \\
\text { planation of the } \\
\text { importance of } \\
\text { the item but } \\
\text { lacks linking to } \\
\text { the purpose } \\
\text { Clear disclosure } \\
\text { of events. The } \\
\text { good, however } \\
\text { lacks some } \\
\text { depth. } \\
\text { Reasonable } \\
\text { level of willing- } \\
\text { ness to disclose } \\
\text { personal } \\
\text { thoughts, } \\
\text { Some lack of } \\
\text { ability to ex- } \\
\text { epress their feel- } \\
\text { ings resulting in } \\
\text { a surface level } \\
\text { of emotional } \\
\text { maturity and } \\
\text { understanding } \\
\text { Most reflective } \\
\text { writing pieces } \\
\text { demonstrate the } \\
\text { ability to self- } \\
\text { critique in an } \\
\text { eeffective man- } \\
\text { ner and pro- } \\
\end{array}$ & $\begin{array}{l}\text { Some of the } \\
\text { content is ac- } \\
\text { companied by } \\
\text { a caption or ex- } \\
\text { planation of } \\
\text { the importance } \\
\text { of the item. } \\
\text { Minimal link- } \\
\text { age to purpose } \\
\text { Poor recalling } \\
\text { of events } \\
\text { Hesitation } \\
\text { demonstrated } \\
\text { in the disclo- } \\
\text { sure of per- } \\
\text { sonal thoughts, } \\
\text { demonstrating } \\
\text { a surface level } \\
\text { and not an in- } \\
\text { sightful level } \\
\text { of disclosure. }\end{array}$ & $\begin{array}{l}\text { No insight } \\
\text { demonstrated } \\
\text { into the ability } \\
\text { to express or un- } \\
\text { derstanding } \\
\text { their feelings } \\
\text { None of the re- } \\
\text { flective writing } \\
\text { pieces demon- } \\
\text { strate the ability } \\
\text { to self-critique } \\
\text { in an effective } \\
\text { manner. Con- } \\
\text { structive sug- } \\
\text { gestions for } \\
\text { adaptive }\end{array}$ \\
\hline
\end{tabular}


constructive the ability to vides construc- changes in re- changes in resuggestions or self-critique in tive suggestions sponse and be- sponse and begoals for adap- an effective for adaptive haviour. haviour are abtive changes in manner and changes in re- sent, showing response and provides con- sponse and be- no description behaviour. structive sug- haviour. gestions for adaptive of opportunities changes in re-
sponse and be-

for growth and/or goal setting. haviour. 



\subsection{Conclusion}

Bryant and Chittum (2013) call attention to the importance of ePortfolios through their statement that "the current literature suggests that ePortfolio can plausibly make great contributions to student learning when properly implemented," (p. 195). Recognition of the potential of ePortfolios to stimulate learning, support assessment and provide a tool for life-long professional growth is gaining momentum in the higher education sector. ePortfolios are more than another technological tool. They have the potential to provide students with valuable insights into their learning styles and thus enhance the students' degree of self-awareness. For ePortfolios to have the most significant influence on student learning, the design and purpose of the ePortfolio must be considered carefully by the implementing academic(s) and should be fully integrated across a program of learning, not just tacked on as an addition or afterthought. Learning and teaching activities need to be aligned with and supported by authentic and integrated assessment activities to ensure the quality of learning in an ePortfolio. Even though this process of alignment can be timeconsuming, if careful consideration is not taken in the design and implementation process, then ePortfolios can become an "irrelevant activity if implemented inappropriately" (Andre, 2010, p. 123). The strength of ePortfolios lies in their capacity to build reflective ability and when used in both formative and summative formats, feedback over time in an ePortfolio assists students to identify their strengths and stimulates the development of future learning goals (Davis, McKimm \& Forrest, 2013). ePortfolios need to be supported by clear grading rubrics so as to provide students with well-defined objectives and explicit assessment criteria. The use of grading rubrics also supports academics to provide comprehensive feedback to support student learning and progression. In conclusion, eportfolios should not be viewed merely as another assessment item but should be viewed for their potential to create connections and to extend beyond the classroom to facilitate a path of lifelong learning.

\section{References}

A. Buzzetto-More, N., \& Julius Alade, A. (2008). The pentagonal e-Portfolio model for selecting, adopting, building, and implementing an e-Portfolio. Journal Of Information Technology Education: Innovations In Practice, 7, 44-70. doi.org/10.28945/197.

Anderson, L. W., Krathwohl, D. R., \& Bloom, B. S.(2001). A taxonomy for learning, teaching, and assessing: A revision of bloom's taxonomy of educational objectives (Complete ed.). New York: Longman.

Andre, K. (2010). E-Portfolios for the aspiring professional. Collegian, 17(3), 119-124. 
Andre, K., Heartfield, M., \& Cusack, L. (2017). Portfolios for health professionals (3rd ed.). Chatswood: Elsevier.

Association of American Colleges and Universities. (2009). Integrative Learning VALUE Rubric. Retrieved from https://www.aacu.org/value/rubrics/inquiry-analysis

Auburn eportfolio rubric (2016) retrieved from http://wp.auburn.edu/writing/wp-content/uploads/20150806ePortfolioRubric.pdf

Australian ePortfolio Toolkit (2009) AeP Concept Guide for learners retrieved from http://www.eportfoliopractice.qut.edu.au/information2/toolkit/index.jsp

Bacabac, F. (2012). Creating professional ePortfolios in technical writing. Journal Of Business And Technical Communication, 27(1), 91-110. doi.org/10.1177/1050651912458921.

Barrett, H. (2007). Researching electronic portfolios and learner engagement: The REFLECT Initiative. Journal of Adolescent \& Adult Literacy, 50(6), 436-449.

Bennett, D., Richardson, S., \& MacKinnon, P. (2015). Enacting strategies for graduate employability: How universities can best support students to develop generic skills. Sydney: Australian Government Office for Learning and Teaching.

Bennett, D., Rowley, J., Dunbar-Hall, P., Hitchcock, M., \& Blom, D. (2016). Electronic portfolios and learner identity: An ePortfolio case study in music and writing. Journal of Further and Higher Education, 40(1), 107-124. doi.org/10.1080/0309877X.2014.895306.

Blair, H. C, Campbell, C., \& Duffy, M. (2017). A multi-pronged approach to the enterprise-wide implementation of a personal learning environment. Proceedings of 2017 ePortfolio Forum: Owning, Supporting and Sharing the Journey, (pp. 9-17).

Bourner, T. (2003). Assessing reflective learning. Education + Training, 45(5), 267-272.

Brubaker, K. L. (2015). Utilizing the ePortfolio to help create the next stepping stone in an undergraduate student's career. https://digitalcommons.brockport.edu/surc/2015/schedule/115/

Buyarski, C., Aaron, R., Hansen, M., Hollingsworth, C., Johnson, C., \& Kahn, S. et al. (2015). Purpose and Pedagogy: A Conceptual Model for an ePortfolio. Theory Into Practice, 54(4), 283-291.

Cercone, K. (2008). Characteristics of adult learners with implications for online learning design. AACE journal, 16(2), 137-159.

Clarke, J. L., \& Boud, D. (2016). Refocusing portfolio assessment: Curating for feedback and portrayal. Innovations in Education and Teaching International, 55(4) 1-8. doi.org/10.1080/14703297.2016.1250664.

Curtis, R. S., \& Wu, W. (2012). Learning and assessment: The application of ePortfolios. Journal of Higher Education Theory and Practice, 12(3), 66-74.

Davis, M., McKimm, J., \& Forrest, K. (2013). How to assess doctors and health professionals. John Wiley \& Sons.

Driessen, E. W., Overeem, K., Van Tartwijk, J., Van Der Vleuten, C. P., \& Muijtjens, A. M. (2006). Validity of portfolio assessment: Which qualities determine ratings?. Medical Education, 40(9), 862-866. doi: 10.1111/j.1365-2929.2006.02550.x.

Dunn, L., \& Musolino, G. M. (2011). Assessing reflective thinking and approaches to learning. Journal of Allied Health, 40(3), 128-136.

Duncan-Pitt, L., \& Sutherland, S. (2006). An introduction to the use of eportfolios in professional $\begin{array}{llll}\text { practice. Journal of Radiotherapy in Practice, 5(2), 69-75. } & \end{array}$ doi.org/10.1017/S1460396906000100.

Fitch, D., Peet, M., Reed, B. G., \& Tolman, R. (2008). The use of ePortfolios in evaluating the curriculum and student learning. Journal of Social Work Education,44(3), 37-54. doi.org/10.5175/JSWE.2008.200700010.

Green, J., Wyllie, A., \& Jackson, D. (2014). Electronic portfolios in nursing education: A review of the literature. Nurse Education In Practice, 14(1), 4-8. doi: 10.1016/j.nepr.2013.08.011.

Hallam, G., \& Creagh, T. (2010). ePortfolio use by university students in Australia: a review of the Australian ePortfolio project. Higher Education Research \& Development, 29(2), 179-193.

Housego, S., \& Parker, N. (2009). Positioning ePortfolios in an integrated curriculum. Education + Training, 51(5/6), 408-421. doi.org/10.1108/00400910910987219/ 
Kolb, D. A. (2014). Experiential learning: Experience as the source of learning and development. FT press.

Krathwohl, D. R., Bloom, B. S., \& Masia, B. B. (1964). Taxonomy of educational objectives, handbook ii: affective domain. New York: David McKay Company.

Lambert, S., \& Corrin, L. (2007). Moving towards a university wide implementation of an ePortfolio tool. Australasian Journal of Educational Technology, 23(1), 1-16.

Light, T. P., Chen, H. L., \& Ittelson, J. C. (2011). Documenting learning with ePortfolios: A guide for college instructors. John Wiley \& Sons.

Lizzio, A. (2011). The student lifecycle: An integrative framework for guiding practice. Brisbane: Griffith University.

McLachlan, K., Yeomans, L., \& Lim, K-Z-G. (2017). Exploring an approach to embedding employability skills in a Work Integrated Learning curriculum. In R.G. Walker \& S.B. Bedford (Eds.), Research and Development in Higher Education: Curriculum Transformation, 40 (pp 241-249). Sydney, Australia, 27-30 June 2017.

Mason, R., Pegler, C., \& Weller, M. (2004). E-portfolios: An assessment tool for online courses. British Journal of Educational Technology, 35(6), 717-727.

Matthews-DeNatale, G. (2013). Are we who we think we are? ePortfolios as a tool for curriculum redesign. Journal of Asynchronous Learning Networks, 17(4), 41-55

Matthews-DeNatale, G. (2013). Seeing the forest for the trees. http://www.neu.mcnrc.org/socpractice/. Accessed $1^{\text {st }}$ November, 2018.

Matthews-DeNatale, G., Blevins-Bohanan, S. J., Rothwell, C. G., \& Wehlburg, C. M. (2017). Redesigning learning: ePortfolios in Support of Reflective Growth within Individuals and Organizations. In Field Guide to Eportfolio: Why it Matters to Learning, (pp. 14-24), Washington DC: AACU

Ng, C. K., White, P., \& McKay, J. C. (2007). A review of the development of electronic portfolios in education and health care disciplines: Supporting students' learning and continuing professional development. Radiographer, 54(3), 24-29.

Pelliccione, L., \& Dixon, K. (2008). ePortfolios: Beyond assessment to empowerment in the learning landscape. Hello! Where are you in the landscape of educational technology. Proceedings ascilite Melbourne 2008. http://www.ascilite.org.au/conferences/melbourne08/procs/pelliccione.pdf. Accessed $1^{\text {st }}$ November, 2018.

Reynolds, C., \& Patton, J. (2014). Leveraging the ePortfolio for integrative learning: A faculty guide to classroom practices for transforming student learning . Sterling, Virginia: Stylus.

Rowley, J., Bennett, D., Blom, D., \& Dunbar-Hall, P. (2014). Exploring the pedagogy and impact of technology on eportfolio creation for arts students in Australian tertiary study. UAE Journal of Eduational Technology and eLearning(5)December, 36-45.

Schön, D. A. (1983). The reflective practitioner: How professionals think in action. In Rowley, J., Bennett, D., Blom, D., \& Dunbar-Hall, P. (2014). Exploring the pedagogy and impact of technology on ePortfolio creation for arts students in Australian tertiary study.

Sutherland, S., Brotchie, J., \& Chesney, S. (2011). Pebblegogy: Ideas and activities to inspire and engage learners. Pebble Learning Limited, e-Innovative Centre, University of Wolverhampton.

Tailor, A., Dubrey, S., \& Das, S. (2014). Opinions of the ePortfolio and workplace-based assessments: A survey of core medical trainees and their supervisors. Clinical Medicine, 14(5), 510516. doi: $10.7861 /$ clinmedicine. $14-5-510$

Tosh, D., Werdmuller, B., Chen, H. L., Light, T. P., \& Haywood, J. (2006). The learning landscape: A conceptual framework for ePortfolios. In Jafari, A. (Ed.). (2006). Handbook of Research on ePortfolios (pp. 24-32). IGI Global.

University of New South Wales (UNSW) (2018). Assessing with ePortfolios. https://teaching.unsw.edu.au/assessing-eportfolios_Accessed date: 1 November 2018.

Vandervelde, J. (2018). EPortfolio (Digital Portfolio) rubric, https://www2.uwstout.edu/content/profdev/rubrics/eportfoliorubric.html. Accessed 28 November 2018. 
Watty, K., \& McKay, J. (2015). Pedagogy and ePortfolios: purpose aligned to design (or the why and how). International Journal of Pedagogies and Learning, 10(3), 194-207.

Zaldivar, M., Summers, T., \& Watson, C. W. (2011) Balancing Learning and Assessment: A study of Virginia Tech's use of ePortfolios In K. V. Wills\& R. Rice. (Eds.). (2011). ePortfolio performance support systems: Constructing, presenting, and assessing portfolios. (pp. 221-239). Colorado, USA: The WAC Clearninghouse. 